\title{
A New Genus and a New Species of Pelagic Ostracods of the Subfamily Halocypridinae from the North Pacific
}

\section{$\operatorname{AUTHOR}(\mathrm{S}):$}

CHAVTUR, VLADIMIR G.; STOVBUN, GALINA G.

\section{CITATION:}

CHAVTUR, VLADIMIR G....[et al]. A New Genus and a New Species of Pelagic Ostracods of the Subfamily Halocypridinae from the North Pacific. Publications of the Seto Marine Biological Laboratory 2008, 40(5-6): 47-54

\section{ISSUE DATE:}

2008-04-30

URL:

http://hdl.handle.net/2433/72818

RIGHT: 


\title{
A New Genus and a New Species of Pelagic Ostracods of the Subfamily Halocypridinae from the North Pacific
}

\author{
Vladimir G. Chavtur and Galina G. Stovbun \\ Laboratory of Planktonology, Institute of Marine Biology, Far East Branch, \\ Russian Academy of Science, Vladivostok 690041, Russia \\ vchavtur@imb.dvo.ru
}

\begin{abstract}
Halocypretta, a new genus of halocypridine ostracods in the subfamily Halocypridinae is proposed for $H$. parvirostrata, new species in the North Pacific and for H. striata (Müller, 1906) in the Indian ocean. New genus and species are described and illustrated. Keys to all genera of this subfamily and to all species of the new genus are presented.
\end{abstract}

Key words: pelagic ostracods, Halocyprididae, Halocypretta, North Pacific

\section{Introduction}

Three genera have been known for the subfamily Halocypridinae Claus, 1891: Halocypris Dana, 1853, Halocypria Claus, 1874 and Felia Poulsen, 1969. All of them are well differed each other primarily by the shape of the ostracod carapace. As shown by Poulsen (1969), the structure of masticatory pad on the mandible is also a reliable character for identification of these genera.

In planktonic samples collected by Russian expeditions in 1966 and 1969 from the deep water layers of the North Pacific, some ostracod specimens were found, which were previously ascribed to a known species - Halocypris striata (Chavtur, 1977a, 1977b, 1977c, 1991, 1992), noted in the Indian Ocean before (Müller, 1906). Additional examination of these specimens enabled to rename them as new species and to place to Halocypretta, new genus. First of all this is based on the differences in the shape and structure of the carapace and mandible. Undoubtedly, H. striata also belongs to the new genus, although its brief description (Müller, 1906) is limited only to the shell, frontal organ and antennae. Descriptions and figures for the new taxon, and keys to all genera of the subfamily Halocyprinae and to all species of the new genus are given below.

\section{Systematics}

\section{Order HALOCYPRIDA Dana, 1853 Suborder HALOCYPRIDINA Dana, 1853 Superfamily HALOCYPRIDOIDEA Dana, 1853 \\ Family HALOCYPRIDIDAE Dana, 1853 Subfamily HALOCYPRIDINAE Claus, 1891}

The subfamily Halocyprinae contains four genera: Halocypris Dana, 1853, Halocypria Claus, 1871, Felia Poulsen, 1969 and Halocypretta, new genus.

\section{Key to Genera of Subfamily Halocyprinae}

1. Rostrum of shell is developed, rostral incisure present; basale endite of mandible with lateral triangular tooth, masticatory surface of coxale endite bears 1 - 4 (5) flaps and 4 large prolonged teeth; furca has 8 - 9 pairs of claws 
lateral triangular tooth, masticatory surface of coxale endite bears small triangular tooth; furca has 7 pairs of claws Halocypris

2. Bristles "a" and "b" on endopodite of 2nd antenna are long; epipodite of mandible is undeveloped and bears bristle, masticatory surface of coxale endite with 4 - 5 flaps, 1st segment of endopodite of mandible has 4 - 5 ventral bristles; lateral bristle of maxilla is short

Bristles "a" and "b" on endopodite of 2nd antenna are short; epipodite of mandible is developed and without bristle, masticatory surface of coxale endite with one flap (distally bifurcated), 1st segment of endopodite of mandible without ventral bristles; lateral bristle of maxilla is very long

Halocypria

3. Shell is rounded and armed with anterodorsal horns and with (or without) anteroventral verrucae (in Felia dispar armed only juvenile); masticatory surface of coxale endite of mandible bears 2 broad proximal and 3 narrow distal flaps Felia Shell is prolonged and bare (without horns and verrucae);masticatory surface bears 4 narrow flaps Halocypretta, new genus

\section{Halocypretta, new genus}

Type-species - Halocypretta parvirostrata, new species

\section{Composition}

This genus includes only two species: H. striata (Müller, 1906) and H. parvirostrata, new species. Only males are known for these species.

\section{Description of adult male}

Shell. It is prolonged, bare and ranged from $2.7-3.3 \mathrm{~mm}$ in length. Height of shell is $59-64 \%$ of the length. Anterior, posterior and ventral margins are rounded. Valves have well pronounced shoulder-vaults. Left asymmetrical gland is placed on the dorsal side near the posterodorsal corner, and right gland is at the posteroventral corner. The surface of the shell is without sculpturing or there is a faint indication anteriorly of lines, more or less parallel to ventral and dorsal margins.

Frontal organ. The organ is thin, long and extended considerably beyond the down curving distal segments of the 1st antenna. Capitulum section is bare and approximately $2-4$ times as long as the stem.

First antenna. The limb is 5-jointed and down curved distally. The 2 nd segment bears one dorsal seta, and 4th+5th segments are armed with subequal "a - d" bristles and long "e" bristle.

Second antenna. The exopodite is very thin and longer than the protopodite. The 1st segment of the endopodite is armed with large and very long "a" and "b" bristles. The 2nd segment bears "c", "d" and "e" bristles. Right and left claspers are developed, approximately equal in length and equally curved. The largest bristle "g" is over than twice as long as bristles "h", "I" and "j". The bristles "f" and "g" flatten into a blade distally.

Mandible. The epipodite is slightly developed and bears one bristle. The exopodite is represented by one plumose seta. The 1st segment of the endopodite is armed with one dorsal and 3 lateral slim bristles, and one ventral stout bristle. The 2 nd segment has one stout and 2 slim dorsal bristles, and 2 stout ventral bristles. The 3rd segment carries 7 terminal bristles, of which 1 st and 3 rd dorsal bristles are claw-like. Basale is armed with 2 anteroventral, one anterodorsal and 2 lateral slim bristles, and with anterior dense row of the long hairs near the articulation. Basal endite has tooth edge with 6 distinctly separated terminal and one lateral triangular teeth, and 2 short posterior tube teeth, which are slightly apart. The ventral tooth edge, and distal and proximal tooth rows are borne at the coxale endite. Masticatory surface is armed with 4 narrow rounded flaps and 4 stout prolonged teeth, and covered with numerous long hairs.

Maxilla. The bristle of the basale barely reaches the suture between segments of the endopodite. 
The 1st segment of the endopodite is prolonged and armed with one lateral, 3 posterior and 6 anterior bristles, and with few spinules distally. The 2 nd segment is narrow and bears 3 terminal bristles and subterminal pair of weaker bristles inserted near the base of the central terminal bristle.

Fifth limb. The 1 st endite of the protopodite has 2 bristles and 2 nd endite with 3 bristles. The endopodite bears 8 bristles, of which 2 are claw-like. The 1st segment of the exopodite is armed with one dorsal, 3 lateral and 9 ventral bristles, 2nd with one dorsal and 2 ventral bristles, and 3rd segment with one claw-like (central) and 2 usual terminal bristles.

Sixth limb. The endopodite has 2 bristles. The 1st segment of the exopodite bears 2 dorsal, 2 lateral and 3 ventral bristles, 2nd segment with one ventral bristle, 3rd segment with one ventral and one dorsal bristles, and 4th segment with 3 terminal bristles, of which central bristle is claw-like.

Seventh limb. It is narrow, long and about $1 / 2$ as long as its largest bristle.

Copulatory appendage. The limb is narrow, long and tapering towards the tip.

Caudal furca. This limb has 8 pairs of claws and unpaired bristle.

\section{Remarks}

Insertion of H. striata (Müller) to the new genus is based mainly on likeness in structure and shape of the shell, frontal organ and claspers on the 2 nd antenna in comparison with $H$. parvirostrata, new species. The lack of knowledge of morphology of the mandible, maxilla, 5th-7th limbs, caudal furca and copulatory appendage in H. striata can hardly be an obstacle to its inclusion in this genus.

\section{Comparison}

New genus is closely related to genus Felia, but separated by smaller height of the shell, valves without horns and verrucae, larger rostrum, thinner endopodite and shorter basal seta of the maxilla, and having only narrow flaps at the masticatory surface of the mandible.

\section{Distribution}

Bathypelagic genus. H. striata inhabits in Indian Ocean $\left(20^{\circ} \mathrm{N}, 89^{\circ} \mathrm{E}\right.$, in a tow from $\left.2500-0 \mathrm{~m}\right)$ (Müller, 1906) and probably in Atlantic Ocean (identified as ? Halocypris striata, $37^{\circ} \mathrm{N}, 28^{\circ} \mathrm{W}, 3000$ $0 \mathrm{~m}$ ) (Granata and Caporiacco, 1949). H. parvirostrata, new species, was caught in the KurileKamchatka $\left(43-48^{\circ} \mathrm{N}, 149-153^{\circ} \mathrm{E}\right.$, in the depth range $\left.2250-5500 \mathrm{~m}\right)$, Japan $\left(37^{\circ} \mathrm{N}, 143^{\circ} \mathrm{E}, 2500-2000\right.$ $\mathrm{m})$ and Aleutian $\left(56^{\circ} \mathrm{N}, 137^{\circ} \mathrm{W}, 1500-1000 \mathrm{~m}\right)$ Trenchs.

\section{Key to Species of Halocypretta, new genus}

Anterior margin of the shell extends barely beyond the rostrum; rostrum has angle-like form; surface of the shell without sculpturing; claspers of the 2 nd antenna are narrow proximally H. parvirostrata, new species

Anterior margin of the shell does not extend beyond the rostrum; rostrum has rounded form; surface of the shell with sculpturing; claspers of the 2 nd antenna are thick proximally H. striata (Müller, 1906)

\section{Halocypretta parvirostrata, new species}

(Figs. 1-3)

Halocypria striata: Chavtur, 1977a: 137; 1977b: 30; 1977c: 20; 1991: 48; 1992: table 2

Material examined

Holotype N 1123 - adult male, length $3.30 \mathrm{~mm}$, appendages mounted on slide and valves in alcohol. In collection of the Museum of Institute of Marine Biology, Vladivostok, Russia.

Type-Locality - RV "Vityaz" 39th cruise station $5631,43^{\circ} 43^{\prime} \mathrm{N}, 149^{\circ} 39^{\prime} \mathrm{E}$, depth 5500-5000 m, 3 
September 1966.

Paratype. N 1124 - male, length $3.15 \mathrm{~mm}$ (sample as for holotype).

Additional material. RV "Vityaz" 39th cruise, 1966: adult male, length $2.7 \mathrm{~mm}$ (deformed) and juvenile male, length $2.05 \mathrm{~mm}$, station $5610,48^{\circ} 48^{\prime} \mathrm{N}, 153^{\circ} 13^{\prime} \mathrm{E}$, depth $3000-2500 \mathrm{~m}, 23$ June; juvenile male, length $2.05 \mathrm{~mm}$, station $5612,45^{\circ} 43^{\prime} \mathrm{N}, 153^{\circ} 25^{\prime} \mathrm{E}$, depth $4000-3000 \mathrm{~m}$, $31 \mathrm{July}$; juvenile male, length $2.45 \mathrm{~mm}$, station $5617,45^{\circ} 49^{\prime} \mathrm{N}, 153^{\circ} 33^{\prime} \mathrm{E}$, depth $5000-4000 \mathrm{~m}, 5$ August: 2 juveniles, length $0.85 \mathrm{~mm}$, same station, depth $3377-2250 \mathrm{~m}$; juvenile, station 5627 , length $0.94 \mathrm{~mm}, 44^{\circ} 11^{\prime} \mathrm{N}$, $150^{\circ} 30^{\prime} \mathrm{E}$; depth $3000-2500 \mathrm{~m}, 28$ August; juvenile male, length $2.44 \mathrm{~mm}$ and juvenile, length 0.90 $\mathrm{mm}$, station $5628,43^{\circ} 54^{\prime} \mathrm{N}, 149^{\circ} 47^{\prime} \mathrm{E}$ depth $5000-4000 \mathrm{~m}, 31$ August; adult male, length $3.15 \mathrm{~mm}$, station $5631,43^{\circ} 43^{\prime} \mathrm{N}, 149^{\circ} 39^{\prime} \mathrm{E}$, depth 5500-5000 m, 3 September. RV "Vityaz" 45th cruise, 1969: juvenile, length $1.45 \mathrm{~mm}$, station $6118,56^{\circ} 26^{\prime}-56^{\circ} 28^{\prime} \mathrm{N}, 147^{\circ} 14^{\prime}-136^{\circ} 56^{\prime} \mathrm{W}$, depth $1500-1000 \mathrm{~m}, 18$ May; juvenile (deformed), station $6151,37^{\circ} 38^{\prime}-37^{\circ} 43^{\prime} \mathrm{N}, 143^{\circ} 51^{\prime}-143^{\circ} 52^{\prime} \mathrm{E}$, depth $2500-2000 \mathrm{~m}, 29$ June. All paratypes are kept in collection of the Museum of Institute of Marine Biology, Vladivostok, Russia.

Planktonic materials in the 39th cruise are collected by Bogorov-Rass's Net, $\mathrm{S}=1.0 \mathrm{~m}^{2}$, and material the 45th cruise - by Juday's Net (Oceanic Model), $S=0.5 \mathrm{~m}^{2}$.

\section{Etymology}

The specific name "parvirostrata", from the Latin "parvus" [=small] and "rostra" [=rostrum], refers to size of rostrum, which does not extend beyond the anterior margin of shell.

Description of adult male

Shell (Figs. 1, A and B). The length of the carapace range from $2.7-3.3 \mathrm{~mm}$. The height of shell is about $60 \%$ of the length. Valves are prolonged and with well pronounced shoulder-waults. Anterior, posterior and ventral margins are rounded. Dorsal margin is arched in the anterior part and straight in the medial and posterior parts. Rostrum has angle-like form and does not extends beyond the anterior margin. The asymmetrical gland on the right valve is at the posterior ventral corner and on the left valve opens level with the posterior end of the carapace hinge. The surface of the shell without visible sculpturing.

Frontal organ (Fig. 1, C). It is thin, bare, long and extended considerably beyond the down curving distal segments of the 1st antenna. Capitulum section is concave, rounded at the tip, narrow medially and about 3-4 times as long as the stem. Dorsal margin of the stem is wrinkled.

First antenna (Fig. 1, C and D). The limb is 5-jointed. Outer surface of the 2nd segment is divided by suture near dorsal bristle.The length of this bristle barely exceeds the thickness of the 2nd segment. Surface of the 1st and 2nd segments are covered with small hairs. The bristle "e" bears few small hairs medially, is slightly widened towards the tip, and approximately 5 times as long as the length of the limb and twice of the subequal bristles "a" - "d". Last bristles are bare and tapering towards the tip. A few dark pigment sports are borne at the 1st segment.

Second antenna (Fig. 1, E - G). The exopodite is very slim, narrow medially, and about 1.5 the length of the protopodite. The total length of the 2nd - 9th segments of the exopodite is aproximately $20 \%$ of the 1st segment in length. The bristles "a" and "b" placed at the 1st segment of the endopodite are straight and long. The 2nd segment is armed with long "d" bristle and short "c" and "e" bristles. Left and right claspers are developed, subequal in length, with a tiny point and subterminal ridging, and unswollen distally sharply curved. The largest bristle " $\mathrm{g}$ " is approximately the same length as the 2nd antenna and about 4 times as long as bristles "h","i" and "j". The bristles "f" and "g" flatten into a blade distally.

Mandible (Fig. 2, A - F). The epipodite is developed and with short bristle. The exopodite is represented by long stout and plumose bristle. One short dorsal bristle, 2 long and one short lateral slim bristles, and one long ventral stout bristle are borne at the 1st segment of the endopodite. The 2nd segment is armed with one stout and 2 barely shorter slight dorsal bristles, and 2 long stout ventral 
bristles. The 3rd segment bears lateral row of long hairs and 7 terminal bristles, of which the 1st and 3rd (largest) dorsal bristles are claw-like, and others are usual. Basale carries 2 anteroventral, one anterodorsal and 2 lateral slim bristles, and anterior dense row of the long hairs near the articulation. Basal endite has tooth edge with 6 separated terminal and one lateral triangular teeth, and 2 short posterior tube teeth, which are slightly apart. Coxale is armed with ventral tooth edge, and also distal

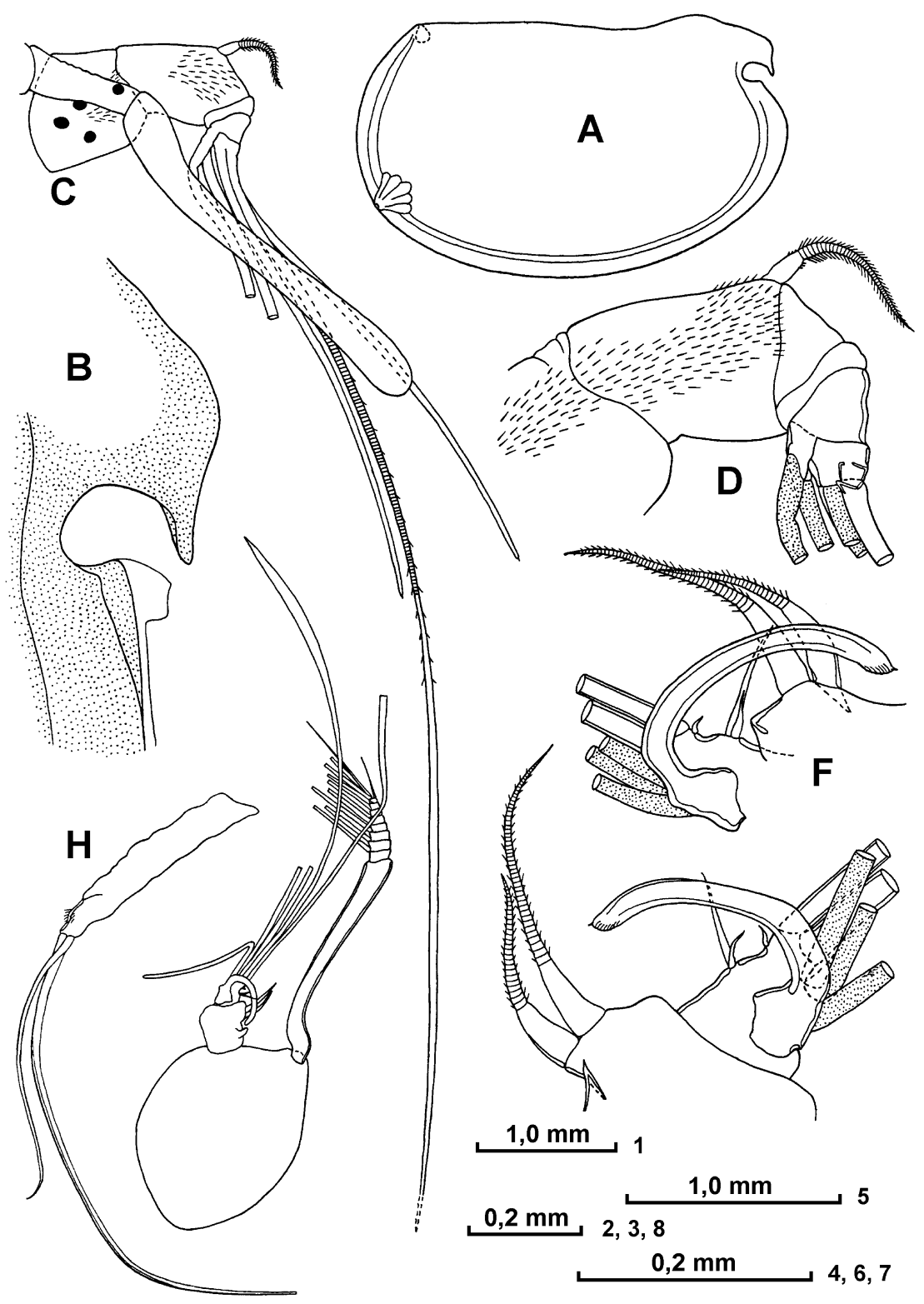

Fig. 1. Halocypretta parvirostrata, new species (male: N 1123 - A, B, E - H; N 1124 - C and D). A-right valve of shell, B-rostrum of right valve, C-frontal organ and 1st antenna, D-1st antenna, E-2nd antenna, F and Gright and left endopodites of 2nd antenna, H-7th limb. 
and proximal tooth rows. Numerous long hairs, 4 narrow rounded flaps, and 4 stout prolonged teeth are placed at the masticatory surface.

Maxilla (Figs. 2, G and 3, A). Basal bristle barely reaches the suture between segments of the endopodite. The $1 \mathrm{st}$ segment of the endopodite is prolonged. Height of the 1 st segment is approximately $50 \%$ the length. One lateral, 3 posterior and 6 anterior bristles, and few terminal

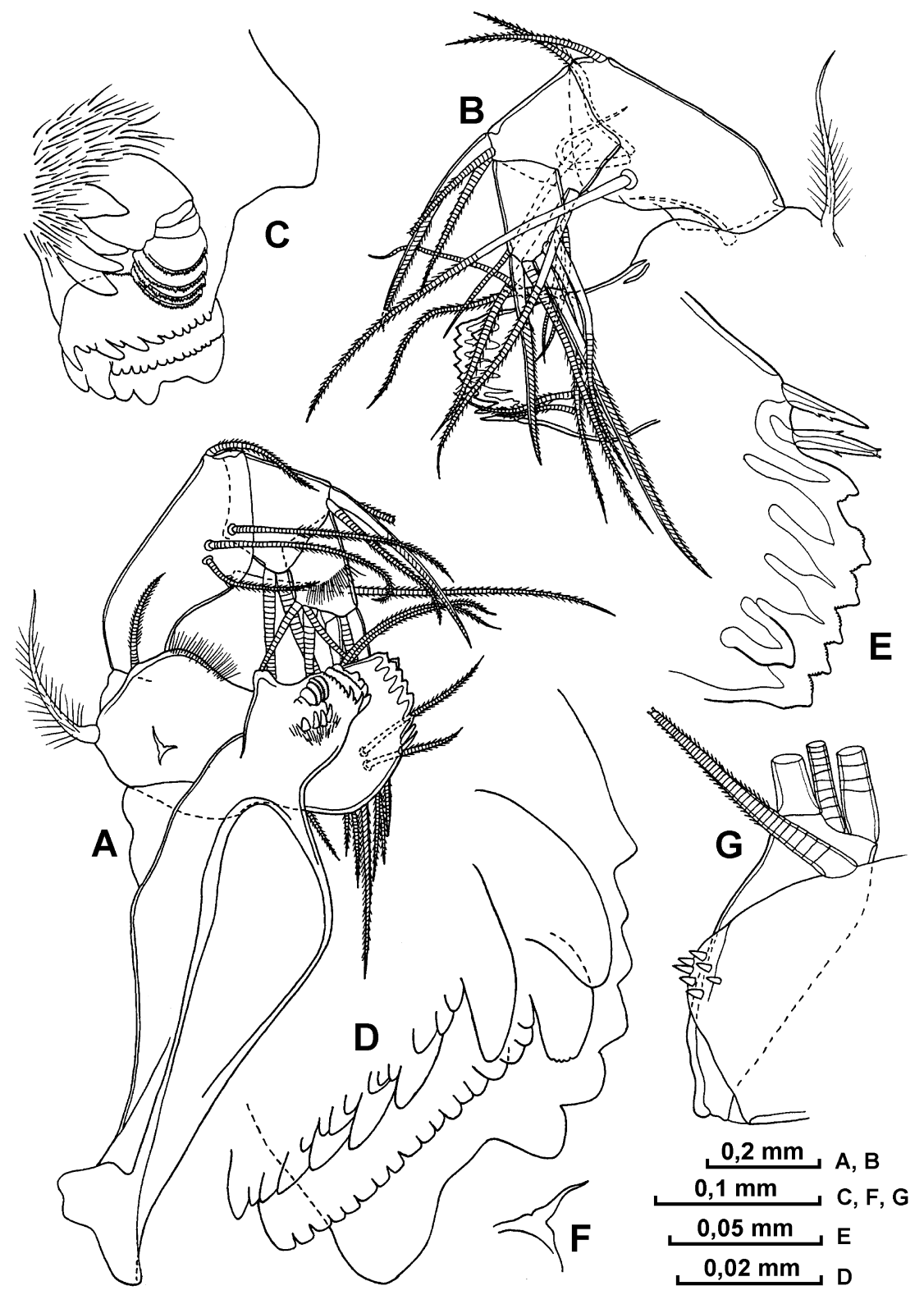

Fig. 2. Halocypretta parvirostrata, new species (male: N 1124 - A - C, F and G; N 1123 - D and E) A and Bmandible, C-coxale of mandible, D-ventral tooth edge, distal and proximal tooth rows of coxale of mandible, E-basal endite of mandible, F-epipodite of mandible, G-distal part of maxilla. 
spinules are placed at this segment. The 2 nd segment is narrow and bears one claw-like (anterior) and 2 usual terminal bristles, and subterminal pair of weaker bristles inserted near the base of the central terminal bristle.

Fifth limb (Fig. 3, B). The epipodite is broken. The 1st endite of the protopodite has one long plumose and one short usual bristles, the 2 nd segment with 2 short usual bristles. The endopodite is armed with 2 claw-like and 6 (one plumose) usual bristles. One dorsal, 3 lateral and 9 ventral bristles

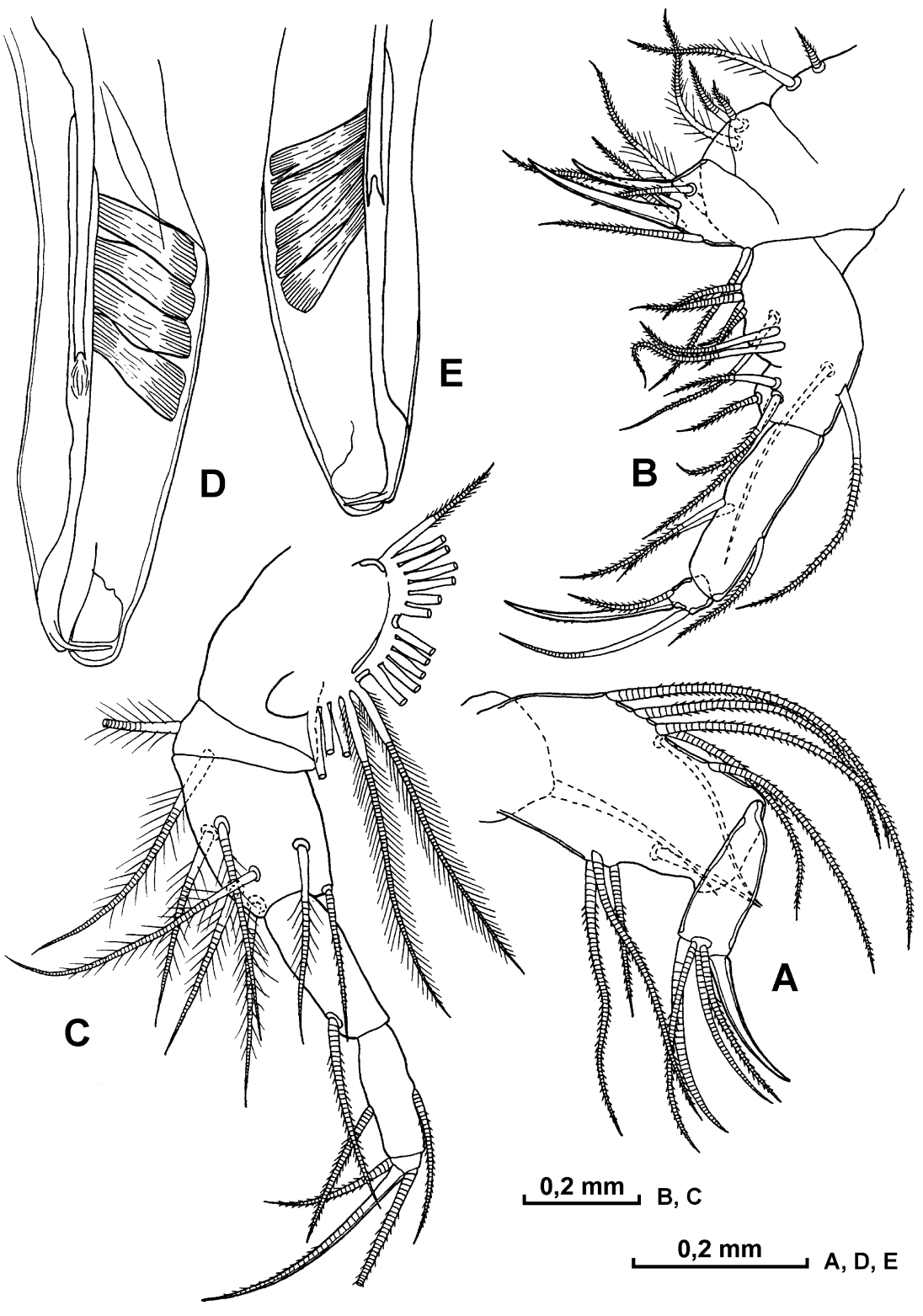

Fig. 3. Halocypretta parvirostrata, new species (male: N 1124 - A, C and E; N 1123 - B and D) A-maxilla, Bfifth limb, C-sixth limb, D and E-copulatory appendage. 
(total 13) are placed at the 1st segment of the exopodite. The 2 nd segment has one dorsal and 2 ventral bristles, and 3rd segment with one claw-like (central) and 2 usual terminal bristles.

Sixth limb (Fig. 3, C). The epipodial appendage has 3 groups of $5+5+6$ (one short) bristles. The endopodite bears 2 long plumose bristles. One dorsal, 3 ventral and 2 lateral plumose bristles, and one dorsal usual bristle are placed at the 1 st segment of the exopodite. The 2 nd segment is armed with one ventral bristle, the 3 rd segment with one ventral and one dorsal bristles, and 4th segment has one clawlike (central) and 2 usual terminal bristles. Interior surface of the endopodite and the 1st segment of the exopodite are covered with hairs.

Seventh limb (Fig. 1, H). The limb is narrow, long and approximately as long as its short bristle and $1 / 2$ the length of the its largest bristle.

Copulatory appendage. (Fig. 3, D and E). It is narrow, slightly curved and tapering towards the tip. Limb is armed with 4-5 oblique muscle bands.

Caudal furca. The limb has 8 pairs of claws and single unpaired bristle.

Comparison

This new species is close to H. striata, but differs in following respects (in brackets for $H$. striata): rostrum has angle-like (rounded) form, anterior margin of the shell barely extends (does not extends) beyond the rostrum, claspers of the 2 nd antenna are narrow (thick) proximally.

Distribution

Bathypelagic species. It inhabits in the North Pacific. This species was caught in regions of the Kurile-Kamchatka, Japan and Aleutian Trenchs in the depth range 1000-5500 m.

\section{Acknowledgements}

I wish to thank Dr. M. E. Vinogradov of Institute of Oceanology, Russian Academy of Sciences, for the plankton materials upon which study is based and for the environmental data presented in the station data herein. Also I am greatly indebted to G.G. Stovbun and A.G. Bashmanov of Institute of Marine Biology, Far East Branch, Russian Academy of Science for technical preparation of this manuscript. This work was supported by the grant from the Russian Fundamental Fund of Investigation (RFFI).

\section{References}

Chavtur, V. G. 1977a. Species composition and vertical distributions of pelagic ostracods in the region of KurileKamchatka Trench. Trudy Instituta okeanologii AN SSSR, 108: 136-164 [In Russian.].

Chavtur, V. G. 1977b. Fauna of pelagic ostracods of the Halocypridae family in the northwestern part of the Pacific ocean. Biologija Morija, 1: 28-38 [In Russian].

Chavtur, V. G. 1977c. Fauna of pelagic ostracods of the Halocypridae family in the northwestern part of the Pacific Ocean. Sov. T. Marine Biology, 3 (3): 18-26.

Chavtur, V. G. 1991. History - bibliographic review and analysis of study recent ostracod - myodocops of the oceans world. Vladivostok DVO AN SSSR. 2 (3): 136 [In Russian].

Chavtur, V. G. 1992. Composition, structure and distribution benthic and pelagic ostracods of the superorder Myodocopa of temperate and cold waters of the Northern Hemisphere. Institute Biologii Morija DVO RAN. Vladivostok:155 pp., 30 figs., 96 bibl. nam. Dep. VINITI, N 3016 - VD 2, 20. 10. 92. [In Russian].

Granata, L.and, Caporiacco, L. 1949. Ostracodes marins recuillis pendant les croisieres du Prince Albert I-er de Monaco. Résultats des campagnes scientifiques accomplies sur son yacht par Albert Ier, 109: 1-51.

Müller, G. W. 1906. Ostracoda. Wissenschaftliche Ergebnisse der deutschen Tiefsee-Expedition. 8: 1-154.

Poulsen, E. M. 1969. Ostracoda - Myodocopa. Pt. III A. Halocypriformes - Thaumatocypridae and Halocypridae. Dana Report, 75: 100 pp. 